Pendas: Primary Education Journal

Volume 2 Nomor 2, Juli-Desember 2021

P-ISSN: 2686-5130 || E-ISSN : 2776-298X

Availabel online at: http://journal.unram.ac.id/index.php/pendas/index

\title{
PENERAPAN PEMBELAJARAN KOOPERATIF MODEL MIND MAPPING UNTUK MENINGKATKAN HASIL BELAJAR SISWA SDN 1 LANDUNGSARI DI MASA PANDEMI COVID-19
}

\author{
Moh. Farid Nurul Anwar ${ }^{1)^{*}}$, Ika Widayanti ${ }^{1)}$ \\ ${ }^{1)}$ Program Studi Pendidikan Guru Sekolah Dasar, Fakultas Ilmu Pendidikan - Universitas Tribhuwana \\ Tunggadewi \\ *Corresponding Author: mohfaridnurulanwar@gmail.com
}

\begin{tabular}{|c|c|}
\hline ARTICLE INFO & ABSTRACT \\
\hline $\begin{array}{l}\text { Article history } \\
\text { Received : October } 28^{\text {st }}, 2021 \\
\text { Revised : November } 29^{\text {st }}, 2021 \\
\text { Accepted : December } 19^{\text {st }}, 2021 \\
\text { Keywords: } \\
\text { Cooperative learning, Mind } \\
\text { Mapping, Learning Outcomes }\end{array}$ & $\begin{array}{l}\text { The learning outcomes of class VIB SDN Landungsari } 1 \text { student did } \\
\text { not reach the specified Minimum Completeness Criteria (MCC). } \\
\text { Apart from the effects of the post-covid-19 pandemic, the cause of the } \\
\text { low student learning scores was the learning model. The learning } \\
\text { model must be following the times. One of the learning models is the } \\
\text { mind mapping model of cooperative learning which is an innovative } \\
\text { learning model. The purpose of this study was to describe the } \\
\text { application of the mind mapping model of cooperative learning to } \\
\text { improve student learning outcomes. This research was conducted in } 2 \\
\text { cycles using the class action research method (CAR) with steps were } \\
\text { action planning, action implementation, evaluation, and reflection in } \\
\text { each cycle. The learning outcomes of cycle } 1 \text { showed the mean of } \\
\text { affective, psychomotor, and cognitive values were } 79.80,62.50 \text {, and } \\
73.84 \text {, respectively. The learning outcomes of cycle } 2 \text { showed an } \\
\text { increase compared to the learning outcomes in preliminary } \\
\text { observation and cycle } 1 \text { with the average values of affective, } \\
\text { psychomotor, and cognitive were } 98,93.75 \text {, and } 86.92, \text { respectively. } \\
\text { The results of this study indicated that the mind mapping model of } \\
\text { cooperative learning could improve student learning outcomes. }\end{array}$ \\
\hline
\end{tabular}

\begin{abstract}
ABSTRAK
Hasil belajar siswa kelas VIB SDN Landungsari 1 belum mencapai Kriteria Ketuntasan Minimum (KKM) yang ditentukan. Selain dampak dari pasca pandemi covid-19, penyebab rendahnya nilai belajar siswa adalah model pembelajaran. Model pembelajaran harus mengikuti perkembangan zaman. Salah satu model pembelajaran adalah pembelajaran kooperatif model mind mapping yang merupakan model pembelajaran inovatif. Tujuan penelitian ini adalah mendeskripsikan penerapan pembelajaran kooperatif model mind mapping untuk meningkatkan hasil belajar siswa. Penelitian ini dilaksanakan dalam 2 siklus dengan menggunakan metode penelitian tindakan kelas (PTK) dengan langkah-langkah perencanaan tindakan, pelaksanaan tindakan, evaluasi, dan refleksi pada setiap siklusnya. Hasil belajar siklus 1 menunjukkan rerata nilai afektif, psikomotorik, dan kognitif masing-masing adalah 79,80, 62,50, dan 73,84. Hasil belajar siklus 2 menunjukkan peningkatan dibandingkan dengan hasil belajar pada observasi awal dan siklus 1 dengan rata-rata nilai afektif, psikomotor, dan kognitif masing-masing adalah 98, 93,75, dan 86,92. Hasil penelitian ini menunjukkan bahwa pembelajaran kooperatif model mind mapping dapat meningkatkan hasil belajar siswa.
\end{abstract}




\section{A. PENDAHULUAN}

Usaha untuk mencerdaskan kehidupan bangsa adalah melalui pendidikan. Pendidikan mempunyai peranan penting dalam meningkatkan kualitas sumber daya manusia dan mampu menghadapi tantangan di masa depan dalam berkompetisi dalam ilmu pengetahuan dan teknologi. Menurut (Rifanty, 2018 : 1) Pendidikan adalah sebuah proses yang akan terus dialami oleh manusia sepanjang hidupnya dari sejak dalam kandungan sampai meninggal dunia. Di Indonesia, Pendidikan bertujuan untuk meningkatkan kualitas manusia Indonesia, yaitu manusia yang beriman dan bertaqwa terhadap Tuhan Yang Maha Esa, berbudi pekerti luhur, berkepribadian, mandiri, maju, tangguh, cerdas, kreatif, terampil, disiplin, profesional, bertanggung jawab dan produktif serta sehat jasmani dan rohani (Winataputra, 2007).

Dalam dunia pendidikan, pembelajaran merupakan bagian yang terpenting. Pendidikan dan pembelajaran merupakan satu kesatuan yang saling terkait. Menurut Pane (dalam Pohan, 2021) pembelajaran merupakan proses interaksi peserta didik dengan guru, dengan bahan pelajaran, metode penyampaian, strategi pembelajaran, dan sumber belajar dalam suatu lingkungan belajar. Pembelajaran merupakan wujud dari pelaksanaan pendidikan. Dalam pembelajaran yang baik, siswa harus dilibatkan secara aktif dan tidak hanya didominasi oleh guru saja. Keterlibatan siswa tersebut seperti keaktifan siswa dalam kelas. Keaktifan siswa membuat proses pembelajaran tidak hanya berlangsung satu arah dan berpusat pada guru, namun pembelajaran berlangsung secara dua arah dan proses pembelajaran tidak menjadikan siswa bosan karena siswa dilibatkan secara aktif oleh guru. Siswa yang dilibatkan secara aktif dalam pembelajaran menjadikan pembelajaran menjadi lebih bermakna.

Keaktifan siswa juga mempengaruhi hasil belajar siswa, jika siswa terlibat secara aktif dalam pembelajaran maka berpengaruh pada hasil belajar. Hasil belajar merupakan perubahan tingkat kemampuan yang diperoleh setelah siswa melakukan proses belajar baik secara tertulis maupun lisan. Menurut (Rusman dalam Nainggolan, 2021 : 2619) mengatakan bahwa hasil belajar adalah sejumlah pengalaman yang diperoleh siswa yang mencakup ranah kognitif, afektif, dan psikomotorik. Sedangkan menurut (Suprijono dalam Widodo, 2013 : 34), hasil belajar adalah pola-pola perbuatan, nilai-nilai, pengertianpengertian, sikap-sikap, apresiasi dan keterampilan.

Menurut Susanto (dalam Nainggolan 2021), hasil belajar meliputi pemahaman konsep (aspek kognitif), keterampilan proses (aspek psikomotorik), dan sikap siswa (aspek afektif). Pemahaman konsep yaitu seberapa besar siswa mampu menerima, menyerap, dan memahami pelajaran yang diberikan oleh guru kepada siswa, atau sejauh mana siswa dapat memahami serta mengerti apa yang ia baca, yang dilihat, yang dialami, atau yang ia rasakan berupa hasil penelitian atau observasi langsung yang ia lakukan. Keterampilan proses merupakan keterampilan yang mengarah kepada pembangunan kemampuan mental, fisik, dan sosial yang mendasar sebagai penggerak kemampuan yang lebih tinggi dalam diri individu siswa. Sikap yaitu kekompakan antara mental dan fisik secara serempak.

Salah satu hal terpenting dalam mencapai hasil belajar siswa adalah melalui model pembelajaran. Demikian halnya di SDN 1 Landungsari, secara keseluruhan pengetahuan, 
keterampilan dan sikap yang merupakan hasil belajar siswa sebagian masih kurang sesuai dengan harapan yaitu memenuhi Kriteria Ketuntasan Minimal (KKM) yang telah ditentukan. Hal tersebut diperoleh dari observasi peneliti saat pada bulan Februari 2021. Berdasarkan hasil observasi, kegiatan pembelajaran dilaksanakan secara daring atau online dikarenakan kendala pandemi covid-19. Dalam pembelajaran secara daring, guru menggunakan model konvensional dan ceramah sehingga pembelajaran kurang efektif , siswa merasa kurang optimal dalam menguasai pembelajaran, dan mengakibatkan pada hasil belajar siswa yang rendah. Hasil belajar siswa yang rendah dibuktikan dengan rekapitulasi nilai harian siswa kelas VI di SDN 1 Landungsari yakni memperoleh nilai rata-rata afektif, psikomotor dan kognitif yaitu 70, 60, 60 dari nilai KKM 70.

Pada bulan September 2021 Wali Kota Malang Sutiaji mengatakan bahwa pembelajaran tatap muka (PTM) secara terbatas akan dimulai, pada Senin 6 September 2021. Pembukaan sekolah di tengah pandemi Covid-19 diawali dengan tahapan uji coba Dibukanya kembali aktivitas belajar mengajar di sekolah karena lantaran PPKM Kota Malang telah turun level menjadi level 3. Penurunan level PPKM berdampak pada kelonggaran sejumlah aktivitas, termasuk pembelajaran tatap muka (Suara Malang, 2021). Berdasarkan hal tersebut, peneliti melaksanakan penelitian lebih lanjut di SDN 1 Landungsari berdasarkan kegiatan observasi awal.

Dari permasalahan yang ada di SDN 1 Landungsari, penerapan model pembelajaran merupakan prioritas utama yang harus diperbaiki. Karena model pembelajaran yang tepat akan berdampak pada hasil belajar siswa. Untuk mengatasi permasalahan tersebut adalah dengan menggunakan model pembelajaran yang melibatkan siswa secara langsung. Menurut Soekamto (dalam Wijaya, 2018), model pembelajaran adalah kerangka konseptual yang melukiskan prosedur yang sistematis dalam mengorganisasikan pengalaman belajar untuk mencapai tujuan belajar tertentu, dan berfungsi sebagai pedoman bagi para perancang pembelajaran dan pengajar dalam merencanakan aktivitas belajar mengajar.

Model pembelajaran kooperatif merupakan suatu model pengajaran dimana siswa belajar dalam kelompok-kelompok kecil yang memiliki tingkat kemampuan berbeda. Setiap anggota saling bekerja sama dan membantu untuk memahami suatu bahan pembelajaran dalam menyelesaikan tugas kelompok (Silviriyanti, 2019). Hal ini sejalan dengan Isjoni (dalam Silviriyanti, 2019), tujuan utama dalam penerapan model belajar mengajar kooperatif adalah agar siswa dapat belajar secara berkelompok bersama temantemannya dengan cara saling menghargai pendapat dan memberikan kesempatan kepada orang lain untuk mengemukakan gagasannya dengan menyampaikan pendapat mereka secara berkelompok.

Dari pernyataan tersebut dapat disimpulkan bahwa model pembelajaran kooperatif adalah suatu model pembelajaran dengan langkah membentuk kelompok-kelompok yang terdiri dari 4-6 siswa yang bertujuan untuk bekerja sama dan belajar bersama agar lebih memahami suatu pembelajaran dan materi.

Salah satu model pembelajaran kooperatif tersebut adalah dengan menggunakan Mind Mapping. Konsep Mind Mapping asal mulanya diperkenalkan oleh Tony Buzan tahun 1970-an. Mind Maping atau Peta Pikiran adalah alternatif pemikiran keseluruhan terhadap pemikiran linier. Mind Mapping menggapai pikiran dari segala arah dan sudut 
(Michalko dalam Buzan, 2007). Senada dengan pemikiran tersebut, Buzan mengungkapkan bahwa Mind Mapping adalah alat berpikir kreatif yang mencerminkan cara kerja alami otak dan cara termudah untuk menempatkan informasi ke dalam otak serta mengambil informai ke luar otak. Selain itu, Mind Mapping juga merupakan cara mencatat yang kreatif, efektif yang akan memetakan pikiran-pikiran kita (Buzan, 2007).

Menggunakan model mind mapping memfokuskan peserta didik agar tidak sulit menguasai pelajaran, cekatan saat menemukan ide baru dengan pemahaman peseta didik yang telah dipelajari memakai bahasa masing-masing dan menjadikan kegiatan pembelajaran lebih bermakna. Menerapkan model ini dapat membantu peserta didik dalam meningkatkan motivasi, minat, kreativitas dan hasil belajar peserta didik (Amin dalam Istiqomah, 2019).

Penelitian yang relevan dengan penelitian ini adalah penelitian yang dilakukan oleh Marxy (2017), pengaruh model pembelajaran mind mapping terhadap hasil belajar matematika siswa. Menurut Zahro V dan Degeng (2018), pengaruh model pembelajaran student team achievement devision (STAD) dan mind mapping terhadap hasil belajar siswa kelas IV sekolah dasar. Penelitian ini mempunyai perbedaan dengan penelitian sebelumnya. Perbedaan penelitian ini dengan yang terdahulu adalah pelaksanaan pembelajaran yang dilaksanakan saat pandemi covid-19. Tujuan diadakannya penelitian ini adalah untuk meningkatkan hasil belajar siswa SDN 1 Landungsari dengan menerapkan pembelajaran kooperatif model pembelajaran mind mapping di masa pandemi covid-19.

\section{B. METODE PENELITIAN}

Penelitian ini menggunakan metode penelitian PTK (Penelitian Tindakan Kelas). Penelitian ini merupakan jenis Penelitian Tindakan Kelas (PTK) dengan desain penelitian Kemmis dan Taggart (1988) yang berbentuk spiral. Setiap siklus meliputi planning (rencana), act (tindakan) and observe (pengamatan), dan reflection (refleksi). Gambaran siklus dalam penelitian ini adalah sebagai berikut:



Penelitian ini dilaksanakan pada September di SDN 1 Landungsari Malang yang beralamat di Jl. Tirto Rahayu No. 72 RT 5 RW 2 Dusun Bendungan, Landungsari, Kec. Dau, Kab. Malang. Subjek penelitian ini adalah siswa kelas VI B yang berjumlah 13 peserta didik yang terdiri dari 8 siswa laki-laki dan 5 siswa perempuan. Subjek pengumpulan data dipilih atas dasar kesepakatan mahasiswa dan guru kelas VI. Objek 
penelitian ini adalah hasil belajar siswa. Instrumen pengumpulan data menggunakan observasi dan tes hasil belajar siswa.

\section{HASIL DAN PEMBAHASAN}

Penelitian ini terdiri dari 2 siklus, yakni siklus 1 dan siklus 2. Pada setiap siklus terdiri dari 4 tahap yitu perencanaan tindakan, pelaksanaan tindakan, observasi, dan refleksi. Pada siklus 1 dan siklus 2 peneliti menjelaskan materi kelas VI tema 2 Persatuan dalam Perbedaan, subtema 2 Bekerja Sama Mencapai Tujuan, pembelajaran 4. Terdapat 2 muatan yaitu muatan PKn dan Bahasa Indonesia. Rencana Pelaksanaan Pembelajaran (RPP) disesuaikan dengan materi yang menggunakan model pembelajaran mind mapping.

Pada siklus 1 pelaksanaan kegiatan dibagi menjadi 3 kegiatan yaitu kegiatan awal, kegiatan inti, dan kegiatan penutup. Pada kegiatan awal menyampaikan salam, doa, menyanyikan lagu nasional, tujuan pembelajaran dan apersepsi. Kegiatan inti, pembelajaran kooperatif digabung dengan model pembelajaran mind mapping. Pada muatan PKn siswa mengamati gambar persatuan dan kesatuan, lalu siswa dapat menyebutkan dan menuliskan sikap yang menunjukkan persatuan dan kesatuan dalam kehidupan sehari-hari. Lalu masuk pada muatan Bahasa Indonesia, siswa diorganisasikan menjadi beberapa kelompok untuk menuliskan kalimat efektif dengan menggunakan model mind mapping tentang perjanjian Linggarjati, perjanjian Renville, perjanjian Roem Roijen, dan Konferensi Meja Bundar. Siswa setelah selesai dalam kerja kelompok akan mempresentasikannya di depan kelas. Sedangkan pada kegiatan penutup terdapat kegiatan tanya jawab, kesimpulan, tindak lanjut, dan doa penutup.

Hasil belajar merupakan tujuan dari pembelajaran yang diukur melalui aspek kognitif, afektif, dan psikomotorik (Kemendikbud, 2013) melalui K13 penilaian ditekankan dengan pendekatan scientific baik proses, sikap, kognitif, dan skill atau keterampilan. Penilaian pada siklus 1 dan siklus 2 digunakan melalui tahap yaitu afektif/sikap (observasi), kognitif (tes hasil belajar), dan psikomotor (praktek).

Penilaian afektif ditinjau berdasarkan hasil observasi, diantaranya penilaian sikap religius siswa yaitu berdo'a sebelum dan sesudah belajar pada siklus 1 dan siklus 2. Pada siklus 1 dari 13 siswa, terdapat 4 siswa yang memperoleh nilai afektif rendah yaitu 62,5. Nilai afektif siswa yang tertinggi dicapai oleh 2 siswa yakni mencapai nilai 100. Rata-rata nilai afektif siswa pada siklus 1 yaitu memperoleh nilai 79,8 .

Penilaian psikomotor ditinjau dari kemampuan siswa secara berkelompok untuk membuat mind mapping bersama kelompoknya dengan menggunakan kalimat efektif dan kata tanya. Berdasarkan hasil kerja kelompok, terdapat 2 kelompok yang memperoleh skor 50, dan kelompok 2 kelompok lainnya memperoleh skor 75. Pada siklus 1 nilai psikomotor siswa mendapatkan rata-rata 62,5. Sehingga, hasil penilaian psikomotor siswa masih tergolong rendah. Sebagian siswa belum mengerti langkah membuat mind mapping dengan menggunakan kalimat efektif dan kata tanya, siswa juga belum menghiasnya dengan menarik. Sehingga dalam penilaian psikomotor perlu adanya bimbingan oleh guru dikarenakan siswa ada yang belum memahami materi.

Penilaian kognitif menunjukkan ada siswa yang tidak tuntas pada soal yang diberikan melalui tes hasil belajar pada siklus 1 . 
Berikut adalah data hasil belajar (kognitif) siswa pada siklus 1 seperti tabel di bawah ini :

Tabel 1.1 Data Nilai Hasil Belajar Siswa Siklus I

\begin{tabular}{|c|c|c|c|c|}
\hline No & Nama Siswa & KKM & Nilai Tes & Keterangan \\
\hline 1. & M. Alvino A. & 70 & 40 & Belum Tuntas \\
\hline 2. & M. Angga Dwi & 70 & 90 & Tuntas \\
\hline 3. & $\mathrm{Na}$ 'ifa Azalia & 70 & 70 & Tuntas \\
\hline 4. & Nikita Agis & 70 & 80 & Tuntas \\
\hline 5. & Nurul Mirza & 70 & 90 & Tuntas \\
\hline 6. & Mila Yulfiana & 70 & 50 & Belum Tuntas \\
\hline 7. & Panji Agung & 70 & 90 & Tuntas \\
\hline 8. & Radhifan Ilham & 70 & 90 & Tuntas \\
\hline 9. & Raka Nur M. & 70 & 60 & Belum Tuntas \\
\hline 10. & Restu Muninggar & 70 & 70 & Tuntas \\
\hline 11. & Riza Indriani & 70 & 90 & Tuntas \\
\hline 12. & Syabila Quinsha & 70 & 80 & Tuntas \\
\hline \multirow[t]{5}{*}{13.} & Zalfah Zahira & 70 & 60 & Belum Tuntas \\
\hline & Jumlah & & 960 & \\
\hline & Rata-rata kelas & & 73,84 & \\
\hline & Nilai tertinggi & & 90 & \\
\hline & Nilai terendah & & 40 & \\
\hline
\end{tabular}

Dari hasil pengamatan pada siklus 1 ini ada siswa yang belum aktif sehingga siswa kurang termotivasi dalam mengikuti pembelajaran. Dari 13 siswa terdapat 8 siswa yang tidak aktif, dan 5 siswa yang aktif. Di samping itu pencapaian nilai hasil belajar juga masih rendah yaitu 40, dan nilai tertinggi 90. Nilai rata-rata 73,84 dengan KKM 70.

Peneliti melakukan kegiatan evaluasi dan refleksi dari kegiatan perencanaan, pelaksanaan dan observasi. Diadakannya refleksi ini diharapkan dapat menemukan kekurangan dan kelebihan selama proses pembelajaran berlangsung sehingga dapat digunakan untuk meningkatkan pembelajaran selanjutnya. Agar dalam pembelajaran dapat berjalan dengan harapan maka solusi yang ditempuh adalah harus lebih banyak mendorong siswa untuk aktif dalam pembelajaran, memotivasi semua anggota kelompok untuk aktif mengerjakan tugas dan rajin dalam belajar, dan menggunakan model pembelajaran yang tepat sesuai dengan materi yang diajarkan. Untuk memperoleh hasil belajar afektif, kognitif, dan psikomotorik yang lebih baik maka dilakukan perbaikan pembelajaran siklus 2.

Pada siklus 2 dibagi menjadi 4 tindakan, yaitu perencanaan tindakan, pelaksanaan tindakan, evaluasi, dan refleksi. Langkah - langkah yang ditempuh pada siklus 2 hampir sama dengan langkah - langkah pada siklus 1 . Hal yang membedakan siklus 1 dengan siklus 2 adalah pada perencanaannya. Perencanaan siklus 2 didasari oleh hasil refleksi siklus 1, sehingga kekurangan dan kelemahan pada siklus 1 tidak terjadi pada siklus 2. 
Pada siklus 2 terdapat perencanaan tindakan yaitu menggunakan perangkat pembelajaran dan model pembelajaran yang sama dengan yang digunakan pada siklus 1 . Pada perencanaan tindakan siklus 2, peneliti sebagai guru mengadakan perbaikan yang akan dilakukan yaitu agar proses pembelajaran lebih optimal. Perbaikan-perbaikan yang dilakukan pada siklus 2 yaitu memperbaiki perangkat pembelajaran yang digunakan (RPP), memilih model pembelajaran yang tepat yakni model pembelajaran mind mapping, menggunakan media pembelajaran yang tepat seperti power point, memberikan motivasi dan perhatian khusus kepada siswa untuk bertanya apabila ada materi yang kurang difahami dan kepada siswa yang kurang aktif.

Dalam pelaksanaan tindakan, merupakan implementasi dari perencanaan tindakan yang telah diperbaiki, mengenai perbaikan perangkat pembelajaran (RPP), penggunaan model maupun media pembelajaran dan lembar evaluasi. Pembelajaran tindakan pada siklus 2 ini merupakan kelanjutan dari tindakan siklus 1. Pada kegiatan awal terdapat salam, doa, presensi, mengondidikan siswa agar semangat dengan mengajak bertepuk tangan dan menyanyikan lagu nasional. Selanjutnya kegiatan apersepsi guru mengadakan tanya jawab yang berkaitan dengan materi sebelumnya dan mengaitkan dengan materi yang akan dipelajari hari ini. Guru menjelaskan tujuan pembelajaran atau kompetensi dasar yang akan dicapai, yaitu tentang "Rukun dalam Perbedaan “. Setelah siswa dalam kondisi siap belajar, guru masuk pada kegiatan inti pembelajaran.

Pada kegiatan inti, pembelajaran kooperatif digabung dengan model mind mapping. Dengan langkah sebagai berikut.

\section{Tabel 2 Langkah Pembelajaran Kooperatif Model Mind Mapping}

a. Guru menyampaikan kompetensi yang akan dicapai pada Tema 2 Persatuan dalam Perbedaan Subtema 2 Pembelajaran 4.

b. Guru membagi siswa menjadi 4 kelompok dengan materi perjanjian Linggarjati, Renville, Roem Roijen, dan KMB.

c. Guru membagikan LKK (Lembar Kerja Kelompok) yang berbentuk mind mapping pada setiap kelompok.

d. Guru menjelaskan cara untuk berdiskusi dengan kelompok serta cara mengerjakan LKK (Lembar Kerja Kelompok) yang dibagikan. Siswa dalam kelompok dapat menuliskan informasi penting pada mind mapping dengan menggunakan kalimat efektif pada materi yang sudah ditentukan dalam setiap kelompok.

e. Kelompok dapat menemukan informasi penting tersebut dari buku tema maupun buku lks.

f. LKK (Lembar Kerja Kelompok) dapat dihias semenarik mungkin menggunakan pensil warna maupun spidol.

g. Kelompok yang sudah selesai mengerjakan dapat maju untuk mempresentasikan hasil diskusinya untuk dibahas bersama dengan guru dan kelompok lain.

h. Guru dan siswa mengevaluasi hasil kerja secara menyeluruh.

Pada kegiatan penutup, memberi kesempatan kepada siswa yang belum faham untuk bertanya, dilanjutkan dengan kegiatan refleksi oleh siswa. Kemudian membagikan lembar 
evaluasi untuk dikerjakan siswa secara individu. Setelah selesai hasil pekerjaan siswa dikumpulkan dan diserahkan. Untuk menutup pelajaran diberikan tugas pekerjaan rumah dan memimpin doa serta memberi motivasi dan nasihat-nasihat supaya siswa rajin belajar di sekolah maupun di rumah.

Hasil belajar merupakan tujuan dari pembelajaran yang diukur melalui aspek kognitif, afektif, dan psikomotorik (Kemendikbud, 2013) melalui K13 penilaian ditekankan dengan pendekatan scientific baik proses, sikap, kognitif, dan skill atau keterampilan. Penilaian pada siklus 1 dan siklus 2 digunakan melalui tahap yaitu afektif/sikap (observasi), kognitif (tes hasil belajar), dan psikomotor (praktek).

Penilaian afektif ditinjau berdasarkan hasil observasi, yaitu sikap religius berdo'a sebelum dan sesudah belajar. Pada siklus 2 mendapatkan nilai afektif rata-rata sangat baik dan terdapat peningkatan yaitu 98. Seluruh siswa sudah tertib dan khusyu dalam berdo'a sebelum dan sesudah belajar.

Setelah tahapan perencanaan hingga observasi dilakukan, peneliti kembali melakukan evaluasi dan refleksi terhadap hasil atau temuan yang telah tercatat dalam lembar observasi. Tujuan dari evaluasi dan refleksi siklus 2 ini untuk mengetahui peningkatan hasil belajar siswa dalam menguasai materi yang dipelajari. Pada akhir kegiatan pembelajaran siklus 2, diadakan tes untuk menilai kemampuan kognitif hasil belajar siswa. Pada penilaian kognitif, data hasil belajar seluruh siswa menunjukkan nilai ketuntasan dengan jumlah 1.130, dengan nilai rata-rata kelas 86,92. Diperoleh nilai tertinggi 100, dan nilai terendah 70. Adapun hasil belajar siswa pada siklus 2 seperti pada tabel dibawah ini.

Tabel 3 Data Nilai Hasil Belajar Siswa Siklus II

\begin{tabular}{lllll}
\hline No & \multicolumn{1}{c}{ Nama Siswa } & \multicolumn{1}{c}{ KKM } & \multicolumn{1}{c}{ Nilai Tes } & \multicolumn{1}{c}{ Keterangan } \\
\hline 1. & M. Alvino A. & 70 & 80 & Tuntas \\
2. & M. Angga Dwi & 70 & 100 & Tuntas \\
3. & Na'ifa Azalia & 70 & 80 & Tuntas \\
4. & Nikita Agis & 70 & 90 & Tuntas \\
5. & Nurul Mirza & 70 & 90 & Tuntas \\
6. & Mila Yulfiana & 70 & 70 & Tuntas \\
7. & Panji Agung & 70 & 100 & Tuntas \\
8. & Radhifan Ilham & 70 & 100 & Tuntas \\
9. & Raka Nur M. & 70 & 70 & Tuntas \\
10. & Restu Muninggar & 70 & 70 & Tuntas \\
11. & Riza Indriani & 70 & 100 & Tuntas \\
12. & Syabila Quinsha & 70 & 100 & Tuntas \\
13. & Zalfah Zahira & 70 & 80 & Tuntas \\
& Jumlah & & 1.130 & \\
& Rata-rata kelas & & 86,92 & \\
& Nilai tertinggi & & 100 & \\
\hline & Nilai terendah & & 70 & \\
\hline
\end{tabular}


Pada penilaian psikomotor, ditinjau dari hasil kerja kelompok siswa berupa lembar kerja kelompok yaitu membuat mind mapping sesuai dengan materi perjanjian linggarjati, renville, roem roijen, dan kmb. Setelah membuat mind mapping siswa mempresentasikannya di depan kelas bersama dengan kelompok. Berdasarkan hasil kerja kelompok, semua kelompok mendapatkan skor yang baik, yaitu kelompok 1 mendapatkan skor 75, kelompok 2 mendapatkan skor 100, kelompok 3 mendapatkan skor 100, dan kelompok 4 mendapatkan skor 100. Berdasarkan nilai tersebut, diperoleh rata-rata 93,75. Siswa lebih aktif dalam kegiatan tanya jawab dibuktikan saat ada satu kelompok yang maju, setiap kelompok memberikan pertanyaan pada kelompok yang maju tersebut. Misalnya, saat ada temannya dari kelompok 3 bertanya pada kelompok 4 yang membahas KMB.

Kelompok 3 bertanya mengapa perjanjian KMB dinamakan dengan Konferensi Meja Bundar, dan kelompok 4 menjawabnya. Dalam melakukan diskusi kelompok semua siswa lebih aktif dan tidak ada lagi siswa yang pasif. Model pembelajaran mind mapping juga memudahkan siswa dalam memahami materi. Media pembelajaran yang disiapkan oleh guru juga sudah memadai sesuai dengan materi yang diberikan. Kegiatan pembelajaran lancar dan tertib, semua siswa dapat mengamati dan mendiskusikan dengan teman kelompoknya. Interaksi siswa dengan siswa, siswa dengan guru terjalin dengan baik. Siswa sudah berani bertanya kepada guru apabila ada materi yang belum jelas. Proses pembelajaran terlaksana dengan aman, tertib, lancar dan sukses.

Berdasarkan hasil pengamatan dan hasil tes belajar siswa terdapat peningkatan diantaranya, siswa lebih semangat dalam pembelajaran, siswa lebih kreatif karena didukung menggunakan model dan media pembelajaran yang sesuai, semua siswa aktif dalam proses pembelajaran, dan nilai tes kognitif hasil belajar siswa meningkat, dapat dilihat dari tabel perbandingan sebagai berikut.

Tabel 4. Perbandingan Nilai Hasil Belajar Siswa Siklus I dan Siklus II

\begin{tabular}{|c|c|c|c|}
\hline No & Nama Siswa & Nilai Siklus I & Nilai Siklus II \\
\hline 1. & M. Alvino A. & 40 & 80 \\
\hline 2. & M. Angga Dwi & 90 & 100 \\
\hline 3. & Na'ifa Azalia & 70 & 80 \\
\hline 4. & Nikita Agis & 80 & 90 \\
\hline 5. & Nurul Mirza & 90 & 90 \\
\hline 6. & Mila Yulfiana & 50 & 70 \\
\hline 7. & Panji Agung & 90 & 100 \\
\hline 8. & Radhifan Ilham & 90 & 100 \\
\hline 9. & Raka Nur M. & 60 & 70 \\
\hline 10. & Restu Muninggar & 70 & 70 \\
\hline 11. & Riza Indriani & 90 & 100 \\
\hline 12. & Syabila Quinsha & 80 & 100 \\
\hline \multirow[t]{2}{*}{13.} & Zalfah Zahira & 60 & 80 \\
\hline & Jumlah & 960 & 1.130 \\
\hline
\end{tabular}




\begin{tabular}{llll}
\hline No & \multicolumn{1}{c}{ Nama Siswa } & \multicolumn{1}{c}{ Nilai Siklus I } & \multicolumn{1}{c}{ Nilai Siklus II } \\
\hline & Rata-rata kelas & 73,84 & 86,92 \\
& Nilai tertinggi & 90 & 100 \\
& Nilai terendah & 40 & 70 \\
\hline
\end{tabular}

Pada siklus 1 diperoleh rata-rata nilai afektif siswa yaitu memperoleh nilai 79,80, nilai rata-rata psikomotor 62,50 , dan nilai rata-rata kognitif siswa mendapatkan 73,80. Pada siklus 2 terdapat peningkatan yaitu memperoleh nilai rata-rata afektif sebanyak 98 , nilai rata-rata psikomotor 93,75, dan nilai rata-rata kognitif siswa adalah 86,92. Jadi, berdasarkan data pada siklus 2 Penelitian Tindakan Kelas ini dikatakan telah berhasil.

\section{PENUTUP}

\section{Simpulan}

Dari hasil penelitian tindakan kelas yang telah dilaksanakan dapat ditarik kesimpulan bahwa dengan menggunakan model pembelajaran mind mapping dapat meningkatkan hasil belajar siswa kelas VI Tema 2 Subtema 2 Pembelajaran 4 di SDN 1 Landungsari Malang. Hal tersebut dapat dilihat dari rata-rata dan ketuntasan nilai afektif, psikomotor, dan kognitif yang dibandingkan pada nilai tes siklus 1 dengan nilai siklus 2 .

Pada siklus 1 diperoleh rata-rata nilai afektif siswa yaitu memperoleh nilai 79,80 , nilai rata-rata psikomotor 62,50 , dan nilai rata-rata kognitif siswa mendapatkan 73,80 . Pada siklus 2 terdapat peningkatan yaitu memperoleh nilai rata-rata afektif sebanyak 98 , nilai rata-rata psikomotor 93,75, dan nilai rata-rata kognitif siswa adalah 86,92. erdasarkan hasil penelitian menunjukkan terjadi peningkatan hasil belajar dari observasi awal sampai pada siklus 1 dan siklus 2 .

Melalui model mind mapping siswa dapat mengemukakan pendapat secara bebas. Mind mapping merupakan teknik belajar dengan cara membuat catatan kreatif sendirisendiri oleh siswa, sehingga ia dapat menuangkan ide-idenya secara bebas, atau dapat mencatat materi-materi yang diberikan guru dengan menggunakan bahasanya sendiri. Kelebihan lainnya yakni akan membangkitkan semangat belajar siswa. Proses pembelajaran akan lebih kreatif karena semua siswa dapat mengutarakan pendapatnya, siswa akan lebih aktif dan tidak merasa bosan. Sehingga dengan menggunakan model mind mapping ini proses pembelajaran akan lebih menyenangkan, aktif dan kreatif sehingga hasil belajar siswa dapat meningkat.

\section{Saran}

Berdasarkan kesimpulan di atas, berikut beberapa saran yang sebaiknya dilaksanakan oleh guru, siswa, maupun sekolah, yaitu:

1. Bagi guru

Bagi guru diharapkan untuk mencoba menerapkan model Mind Mapping sebagai pengembangan alternative pembelajaran yang inovatif dan variatif dalam meningkatkan aktivitas sehingga hasil belajar yang diperoleh lebih maksimal.

2. Bagi Siswa 
Kepada siswa hendaknya agar selalu giat belajar, aktif, memperhatikan pelajaran, serta berpartisipasi dalam proses pembelajaran sehingga dapat mencapai hasil belajar yang optimal.

3. Bagi Sekolah

Bagi sekolah hendaknya memfasilitasi segala kebutuhan yang diperlukan guru untuk memperlancar proses pembelajaran dan selalu memberikan dukungan kepada guru untuk melaksanakan inovasi pembelajaran.

\section{DAFTAR PUSTAKA}

Buzan, Tony. (2007). Buku Pintar Mind Mapping. Jakarta: PT Gramedia Pustaka Utama. Istiqomah, R. N. (2019). Pengaruh Model Pembelajaran Mind Mapping Terhadap Hasil Belajar Peserta Didik Pada Mata Pelajaran Ipa Kelas V SDN 2 Sidoharjo Pringsewu (Doctoral dissertation, UIN Raden Intan Lampung).

Kemmis, S. and Mc Taggart, R. (1988). The Action Research Planner. Victoria: Deakin University Press.

Marxy, A. (2017). Pengaruh Model Pembelajaran Mind Mapping terhadap Hasil Belajar Matematika Siswa. JKPM (Jurnal Kajian Pendidikan Matematika), 2(2), 173-182.

Nainggolan, M., Tanjung, D. S., \& Simarmata, E. J. (2021). Pengaruh Model Pembelajaran SAVI terhadap Hasil Belajar Matematika Siswa di Sekolah Dasar. Jurnal Basicedu, 5(4), 2617-2625.

Pohan, S. A., \& Dafit, F. (2021). Pelaksanaan Pembelajaran Kurikulum 2013 di Sekolah Dasar. Jurnal Basicedu, 5(3), 1191-1197.

Rifanty, E. (2019). Peningkatan Keaktifan Belajar Menggunakan Model Pembelajaran Kooperatif Tipe Make A Match pada Peserta Didik Kelas VB SD Muhammadiyah Condongcatur. Jurnal PTK Pendidikan Profesi Guru Prajabatan 2018.

Silviriyanti, D. (2010). Penerapan pembelajaran kooperatif model think-pair-share (TPS) untuk meningkatkan aktivitas dan prestasi belajar siswa kelas VIIID semester II SMP Negeri 20 Malang. Penerapan pembelajaran kooperatif model think-pair-share (TPS) untuk meningkatkan aktivitas dan prestasi belajar siswa kelas VIIID semester II SMP Negeri 20 Malang/Desis Silviriyanti.

Widodo, W., \& Widayanti, L. (2013). Peningkatan aktivitas belajar dan hasil belajar siswa dengan metode problem based learning pada siswa kelas viia mts negeri donomulyo kulon progo tahun pelajaran 2012/2013. Jurnal Fisika Indonesia UGM, 17(49), 80105.

Wijaya, H., \& Arismunandar, A. (2018). Pengembangan Model Pembelajaran Kooperatif Tipe STAD Berbasis Media Sosial. Jurnal Jaffray, 16(2), 175-196.

Winataputra Udin S, dkk. 2007. Teori Belajar dan Pembelajaran. Jakarta: Universitas terbuka.

Zahro, F., Degeng, I. N. S., \& Mudiono, A. (2018). Pengaruh model pembelajaran student team achievement devision (STAD) dan mind mapping terhadap hasil belajar siswa kelas IV sekolah dasar. Premiere Educandum: Jurnal Pendidikan Dasar dan Pembelajaran, 8(2), 196. 